\title{
The Influence of Soil and Landfill Leachate Microorganisms in the Degradation of PVC/PCL Films Cast from DMF
}

\author{
Adriana de Campos, José C. Marconato, Sandra M. Martins-Franchetti \\ Departamento de Bioquimica e Microbiologia, UNESP
}

\begin{abstract}
While the use of plastics continues to increase in our daily lives in a growing range products, these materials are very persistent in the environment. The blending of aliphatic polyesters with other thermoplastic polymers is a profitable way of producing materials with changed physical properties and biodegradability, which can facilitate microbial adhesion to the polymer matrix and help to reduce (post-consumer) degradation time of these materials in landfills. This study was an investigation of the biodegradation of films of blends of poly(vinyl chloride (PVC) and poly( $\varepsilon$-caprolactone) (PCL) by soil microorganisms and leachate, by means of respirometry, infrared absorption spectroscopy (FTIR), differential calorimetry scanning (DSC), scanning electron microscopy (SEM), contact angle and weight loss. The results showed that in the soil, the films suffered oxidative biodegradation. The PCL promoted degradation of the PVC in the film of PVC/PCL and the PVC inhibited the rapid degradation of the PCL.
\end{abstract}

Keywords: Polycaprolactone, poly(vinyl chloride), soil, leachate, biodegradation.

\section{Introduction}

Plastics are present in many types of products, but these materials are very persistent in the environment. Biodegradable polymers can solve this problem, because in certain environmental conditions, as in the treatment of municipal waste and industrial biological treatment, these polymers are readily degraded.

In biodegradation, in a favorable environment, enzymes of the biosphere essentially take part in at least one step in the cleavage of the chemical bonds of the material ${ }^{[1]}$. The synthetic biodegradable polymer, poly ( $\varepsilon$-caprolactone) (PCL), which is a linear, hydrophobic and partially crystalline polyester, can be utilized slowly by microorganisms with the enzymes production, before the complete assimilation of the polymer ${ }^{[1,2]}$. It has been reported that degradation of this aliphatic polyester in a living environment can result either from enzymatic attack or from chemical hydrolysis of ester bonds, or both ${ }^{[3]}$.

Its physical properties and commercial availability make PCL very attractive, not only as a substitute for the non biodegradable polymers in commodities, but also for specific applications in medicine and in agricultural areas ${ }^{[1]}$. Up to now, large-scale use of PCL has been limited by its relatively high price. Blending biodegradable polymers with other materials has proved to be an effective and economic way of resolving this problem ${ }^{[4,5]}$. It is well known that PCL forms miscible blends with poly(vinyl chloride) (PVC) in all proportions, the PCL being a very effective plasticizer for the PVC; it is known that this blend is a miscible system due to specific interactions between PVC and $\mathrm{PCL}^{[6,7]}$.

PVC has a variety of important technological applications such as in pipes and pipe connections, films for packaging, window frames, etc ${ }^{[8,9]}$. It thus accumulates in landfills in great quantities and its incineration is toxic, due to the release of hydrogen chloride. This causes serious problems in the treatment of garbage $\mathrm{e}^{[8,10,11]}$. Webb and co-workers ${ }^{[12]}$ studied the biodegradation of PVC plasticized and unplasticized, using the fungus A. pullulans. It was observed that plasticizers may accelerate biodegradation by enhancing fungal adhesion. There are many studies about thermal and photodegradation of $\mathrm{PVC}^{[13,14,15]}$ but there is a few reports available on biodegradation of PVC.

The mixture of different polymers to modify the mechanical and degradational properties may be a way to facilitate microbial adhesion to the polymer matrix and help to reduce the time of degradation of these materials in landfills.

The objective of this research was to examine, by means of a respirometric method ${ }^{[17]}$, contact angle, infrared absorption (FTIR), scanning electron microscopy (SEM), differential scanning calorimetry (DSC) and weight loss, the biodegradation by soil microorganisms and leachate from landfills, of blended films of PCL/PVC obtained by casting.

\section{Materials and Methods}

\section{Film preparation}

PVC were supplied by Sigma-P-9401 (molecular weight of 73,491g. $\mathrm{mol}^{-1}$ ) and PCL were supplied by Solvay-K6800 (molecular weight 85,000 g. $\mathrm{mol}^{-1}$ ).

The homopolymers films were cast by dissolving predetermined weights of each polymer $(0.2000 \mathrm{~g})$ in $8 \mathrm{~mL}$ of N-N-dimethylformamide (DMF) for 1 hour, at $60{ }^{\circ} \mathrm{C}$ and evaporating the final solutions in stainless steel dishes in a vacuum at $60{ }^{\circ} \mathrm{C}$ and $500 \mathrm{mmHg}$. The films were dried in a vacuum for 2 days at room temperature. The blended films were produced by mixing the two polymers $(0.2000 \mathrm{~g}$ in total, PVC/PCL $1: 1 \mathrm{w} / \mathrm{w})$, dissolving the mixture in DMF at $60{ }^{\circ} \mathrm{C}$ and evaporating the solvent in a vacuum, as above. The concentration and quantity of the solution was adjusted to obtain films of $90-110 \mu \mathrm{m}$.

\section{Soil preparation}

Soil was taken from a garden near the Department of Biochemistry and Microbiology (UNESP at Rio Claro, SP, Brazil) and was sifted through a $2 \mathrm{~mm}$ mesh sieve. Water was mixed into the soil to reach its maximum water-holding capacity, $60 \%$. The wet soil was distributed in respirometer flasks in $50 \mathrm{~g}$ aliquots, to which $1 \mathrm{~mL}$ of leachate, taken from the garbage landfill of Piracicaba city (SP, Brazil), was added. The soil and the soil plus landfill leachate (soil/leachate) were left unsterilized in order to use live microorganisms for the biodegradation ${ }^{[18]}$. The landfill leachate had $\mathrm{pH} 7.0$, and, given its origin, certainly containing a

Autor para correspondência: Sandra M. Martins-Franchetti, Departamento de Bioquimica e Microbiologia, Universidade Estadual Paulista "Júlio de Mesquita Filho" - UNESP, Av. 24-A, n 1515, Bela Vista, CP 199, CEP 13506-900, Rio Claro, SP, Brasil, e-mail: samaramf@rc.unesp.br 
diversity of microbes and heavy metals, but these were not identified by qualitative analysis.

The soil was subjected to a chemical analysis following the standard methods of the IAC (Campinas Institute of Agronomy) [19]. The original soil contained $227 \%$ of organic matter (this great value is usual for soils rich in humus) and the mineral particles were $39 \%$ sand, $45 \%$ silt and $16 \%$ clay, with a $\mathrm{pH}$ of 5.9 , which is favorable for microbial activity.

\section{Films characterization}

Respirometric tests: The PVC, PCL and PVC/PCL 1:1 films were buried in non-sterile garden soil and in soil with landfill leachate, inside the respirometer (triplicate tests) at $28{ }^{\circ} \mathrm{C}$, for 120 days, and the accumulation of $\mathrm{CO}_{2}$ was monitored, following the Brazilian technical standard ABNT-NBR $14283^{[17]}$. The tests of biodegradation by respirometry are described in an earlier paper by Campos et al. ${ }^{[18]}$, which gives details of the Brazilian standard ${ }^{[17]}$.

Contact angle measurements: Samples of pre- and post-biotreatment films were placed on flat glass plates and a drop $(20 \mu \mathrm{L})$ of distilled water was deposited on each sample. This drop was illuminated from the side and its image magnified and projected onto a white screen, where the contact angle was measured. The procedure was repeated 3 times and the mean and standard deviation were calculated from these measurements ${ }^{[20]}$. Films post-biotreatment were washed with distilled water, dried with filter paper and kept in desiccator during 48 hours before the contact angle analysis.

Fourier transform infra-red spectroscopy (FTIR): The infrared spectra of polymers and polymer blends were recorded at room temperature, with a Shimadzu FTIR-8300 spectrophotometer of $4 \mathrm{~cm}^{-1}$ resolution.

Scanning electron microscopy (SEM): The morphology of the surfaces of the blend was examined in a scanning electron microscope (Zeiss DSM 940-A), $5 \mathrm{kV}$, covered with gold in a Balzers MED 010 sputter coater.

Differential scanning calorimetry (DSC): DSC thermograms were recorded in a DSC2910 calorimeter, to study the fusion behavior of the samples. Samples of about $6 \mathrm{mg}$ were heated at a rate of $10{ }^{\circ} \mathrm{C} / \mathrm{min}$, from $25^{\circ} \mathrm{C}$ to $250{ }^{\circ} \mathrm{C}$, in a nitrogen atmosphere flowing at $50 \mathrm{~mL} / \mathrm{min}$. To calculate the degree of crystallinity of the blends, the value of $\Delta \mathrm{H}$ for $100 \%$ crystalline PCL was taken as $136 \mathrm{~J} . g^{-1[21]}$.

Weight loss: Films were collected every 30 days for PCL films and every 120 days for PVC and PVC/PCL blends films. Films were washed with distilled water, dried with filter paper and vacuum-dried for 48 hours at $25^{\circ} \mathrm{C}$ before being subjected to analyses. The films weights were measured with an analytical balance.

\section{Results and Discussion}

\section{Respirometric tests}

The mean evolution of $\mathrm{CO}_{2}$ is shown in Figure 1 for the PCL, PVC and PCL/PVC films in soil and soil with leachate. It was observed that the evolution of $\mathrm{CO}_{2}$ in the soil with the PCL film was greater than that with the PVC or PVC/PCL (Figure 1a). The $\mathrm{PVC} / \mathrm{PCL}$ blend in the soil showed a tendency to generate more $\mathrm{CO}_{2}$ than the homopolymer PVC film, although less than PCL alone. The PCL is protected in the blend, due to the interaction between the $\mathrm{HC}-\mathrm{Cl}$ groups of $\mathrm{PVC}$ and $\mathrm{C}=\mathrm{O}$ of $\mathrm{PCL}^{[22]}$. Christensen and coworkers ${ }^{[23]}$ suggest that the excellent miscibility of PCL and PVC perturbs the $\mathrm{C}=\mathrm{O}$ vibration of pure $\mathrm{PCL}$, possibly as result of $\mathrm{Cl} \cdots$ $\mathrm{C}=\mathrm{O}$ interactions. Karal and co-workers ${ }^{[6]}$ also reported that the two components are compatible and that PCL can plasticize PVC at certain dilutions.

The evolution of $\mathrm{CO}_{2}$ in the soil increased with the presence of the pure PVC film, showing that there was some degradation of PVC in the soil, although there are few papers on this subject. Kirbas and coworkers ${ }^{16}$ and Guerzoni and coworkers ${ }^{[24]}$ reported microbial adhesion to PVC water vessels, due to the hydrophobicity of PVC and the lipolytic activity of the microorganisms. According Lucas and co-workers ${ }^{[25]}$ the biodegradation is mainly the result of the activity of microorganisms growing on the surface and/or inside a given material and acting by mechanical, chemical and/or enzymatic means. The degradation of PVC was slower than that of the films of PVC/PCL and PCL. In the case of the soil with leachate, there was no difference in the rate of soil respiration between the tests with PVC, PCL and PVC/PCL films; and even without the film, the evolution of $\mathrm{CO}_{2}$ followed the same trend (Figure 1b). It was observed that leachate hindered the biodegradation of these homopolymers and the blends, possibly because of competition between soil microorganisms and leachate microorganisms.

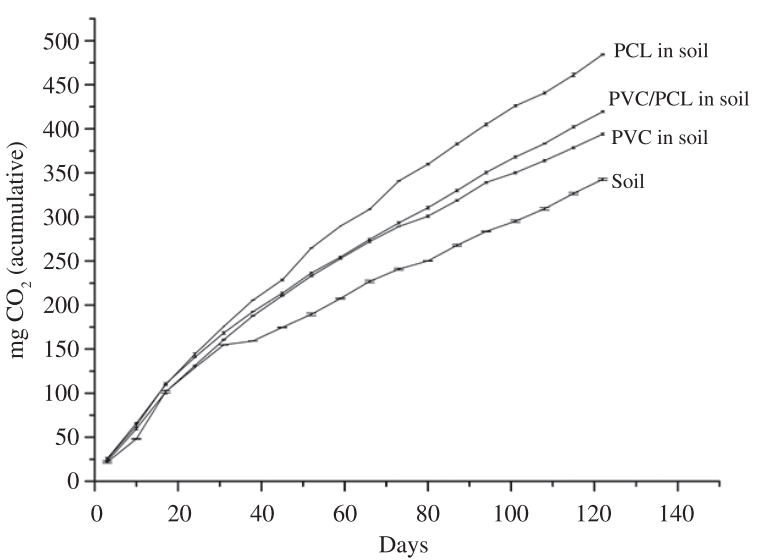

(a)

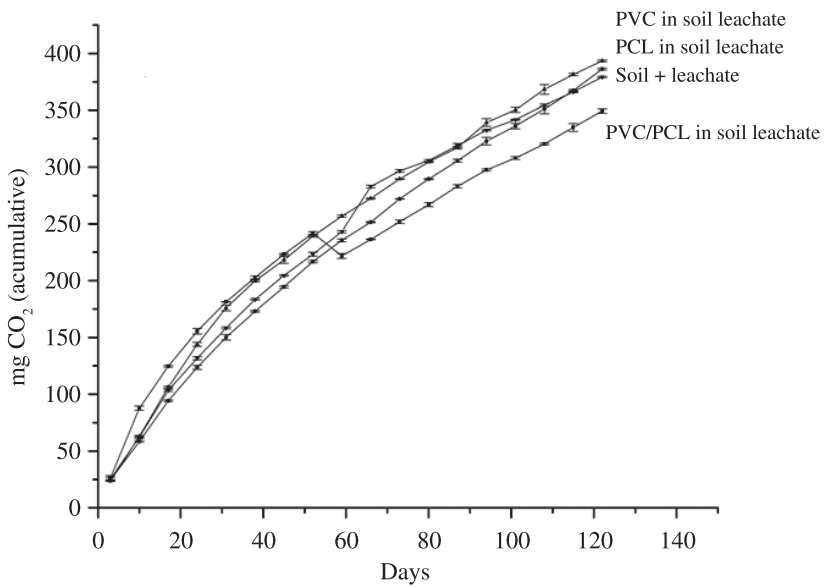

(b)

Figure 1. Production of $\mathrm{CO}_{2}$ accumulated during 120 days of incubation: a) soil, b) soil with leachate. 


\section{Contact angle of films biotreated in soil columns}

Table 1 presents the contact angles measured before and after the microbiological treatments.

The homopolymer PCL films suffered decomposition in the soil, showing more holes on the surface and greater roughness. Therefore, this sample could not be analyzed for contact angle. For the PVC/PCL films, the contact angle decreased after the soil treatment and decreased even more when treated in soil with leachate (Table 1). The same happened to the PVC film.

The results showed that the films became more hydrophilic after the microbial treatment, suggesting the presence of erosions and possible breaks in chains and/or oxidation. According to Luo and co-workers ${ }^{[26]}$, the degradation of PCL happens first in the amorphous area. As a result, the crystallinity of the remained film increased. Initial cool crystallization of the PCL phase in the blend PVC/PCL during solvent evaporation was incomplete due to the presence of the other phase, and as a consequence, the PCL phase continued to crystallize during degradation at $28{ }^{\circ} \mathrm{C}$. After this period, the crystallinity of the samples began to decrease, indicating that the enzymatic attack eroded the crystalline zones gradually.

\section{Infra-red with fourier transform (FTIR)}

The FTIR analyses of PVC films were achieved by $\mathrm{I} / \mathrm{I}_{0}$ standardization of spectra, based on the internal standard band $1252 \mathrm{~cm}^{-1}$. The spectra of PVC films treated in the column of soil and soil with leachate did not show any significant changes after 4 months of treatment (figures are not shown here). As the FTIR spectrometer measures transmission and degradation occurs preferentially on the surface, there were no significant changes in these spectra, although morphological changes did occur. It was not possible to take infrared reflection (ATR) measurements, because the samples had become rigid and rough after the microbial treatment, making their placement on the ATR support difficult.

The initial FTIR analysis of the films of PCL after 30 days of treatment with soil microorganisms and soil with leachate are shown in Figure 2a, b, respectively. The films of PCL were supposed to be taken from the soil after 30 days, 60 days and 90 days of treatment, but were only tested up to 30 days of treatment, because after that, the film showed distortion of the spectra due to irregularities (holes and roughness) and after 90 days, the whole film had disappeared in soil.

The FTIR spectra of the PCL and PVC/PCL films were analyzed qualitatively (i.e., some changes were noted, such as band shifts, and/or the presence or disappearance of new bands), because the low intensity of absorption in the IR, and the complexity of the spectrum in which the absorption overlaps, made it difficult to establish an appropriate baseline (value $\mathrm{I}_{0}$ ), therefore rendering quantitative measurements impractical.

FTIR analysis of the films of PCL after 30 days in the soil (Figure 2a) showed distortion of the spectra due to irregularities (holes and roughness) in the film after the microbial treatment. The PCL film treated in soil with leachate for 30 days (Figure 2b) showed a band shift to $1295 \mathrm{~cm}^{-1}$, which was assigned to the backbone $\mathrm{C}-\mathrm{C}(=\mathrm{O})-\mathrm{O}$ stretching vibration of the crystalline phase of PCL ${ }^{[27,28]}$. It was found that after the treatment, this band doubled in intensity $\left(1299\right.$ and $\left.1289 \mathrm{~cm}^{-1}\right)$. The band at $1182 \mathrm{~cm}^{-1}$, related to axial deformation of $\mathrm{C}-\mathrm{C}(=\mathrm{O})-\mathrm{O}$ was shifted to $1176 \mathrm{~cm}^{-1}$, indicating possible changes in this group.

The FTIR spectra of PVC/PCL films, both untreated and biodegraded, are shown in Figure 3. The spectrum of the PVC/PCL film treated in soil for 120 days (Figure 3 a) showed shifts of the band at $1460 \mathrm{~cm}^{-1}$, (attributed to the vibration of angular deformation of $\mathrm{CH}$ ), the band at $1424 \mathrm{~cm}^{-1}$, (attributed to the axial symmetric deformation of the carboxylate anion), the band at $1354 \mathrm{~cm}^{-1}$, (attributed to the angular deformation of $\mathrm{CH}$ ), and the 1260 and $1099 \mathrm{~cm}^{-1}$ bands, assigned to the asymmetric axial deformation of $\mathrm{COC}$ and axial deformation of $\mathrm{CO}$, respectively.

Table 1. Contact angle $\left({ }^{0}\right)$ after microbiological treatment.

\begin{tabular}{lccc}
\hline \multicolumn{1}{c}{ Films } & original & \multicolumn{1}{c}{ soil } & soil + leachate \\
\hline PCL & 59.5 & ----- & ---- \\
PVC & $72.3 \pm 0.7$ & $49.5 \pm 0.8$ & $44.5 \pm 0.8$ \\
PVC/PCL & $58.7 \pm 0.8$ & $54 \pm 0.5$ & $50.5 \pm 0.8$ \\
\hline
\end{tabular}

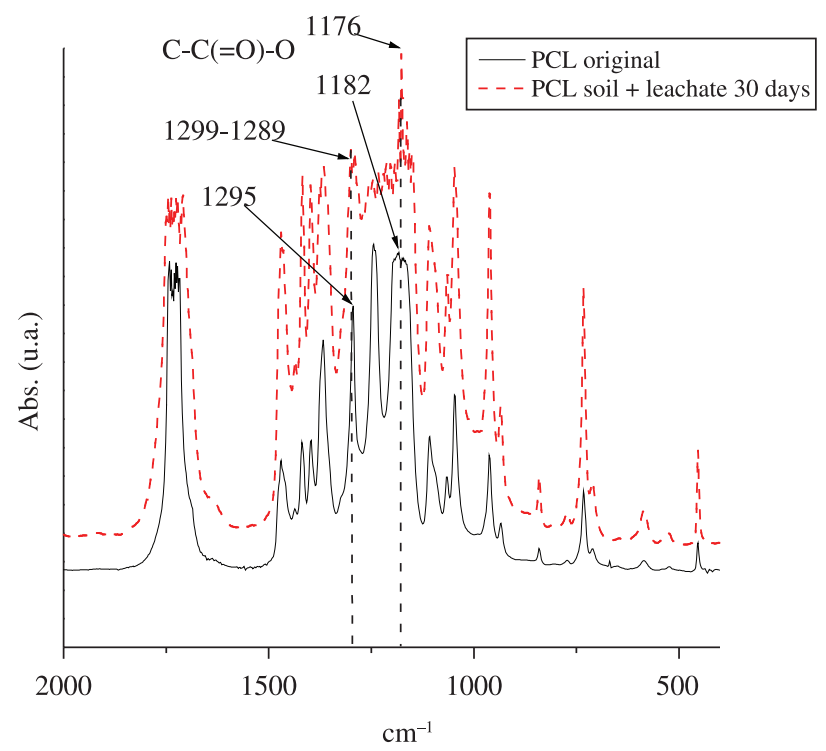

(b) (a)
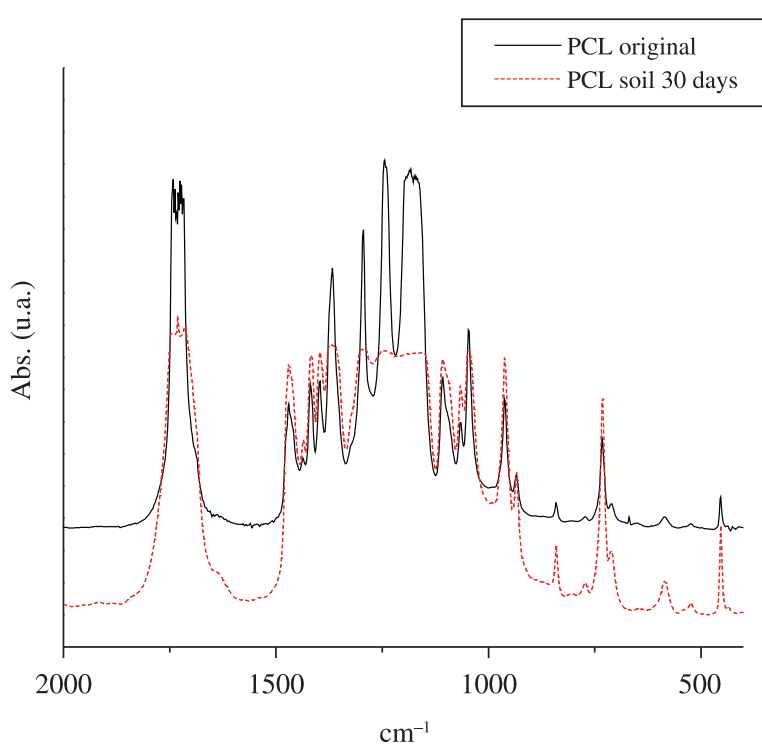

Figure 2. FTIR absorption spectra of the original PCL films and PCL after 30 days in treatment: a) soil, b) soil with leachate. 
The blend, biotreated in soil with leachate for 120 days (Figure 3b), showed a band shift at $1712 \mathrm{~cm}^{-1}$ and $1673 \mathrm{~cm}^{-1}$, attributed to the axial deformation of the carbonyl group. There were also shifts of the bands at 1390 and $1327 \mathrm{~cm}^{-1}$, (assigned to the symmetric angular deformation of $\mathrm{CH}$ and axial deformation of $\mathrm{CO}$, respectively), and the disappearance of the band at $1461 \mathrm{~cm}^{-1}$, (attributed to the angular deformation of $\mathrm{CH}$ ), and 1066 and $1042 \mathrm{~cm}^{-1}$, attributed to the axial deformation of O-C-C. The lack of the band at $734 \mathrm{~cm}^{-1}$, is attributed to the axial deformation of $\mathrm{C}-\mathrm{Cl}$.

The partial degradation of the PVC/PCL blend thus occurred after 120 days of treatment, while that of PCL was observed after 30 days and was complete after 90 days. The degradation of PVC was not evident during the tests.

\section{Scanning electron microscopy (SEM)}

The untreated PVC film (Figure 4a) showed a surface with interconnected areas, similar to gel structures, resulting from the removal of solvent during film drying ${ }^{[29]}$. The PVC film in soil
(Figure 4b) and film in soil with leachate (Figure 4c) show rough structures different from those present in the untreated film. This change in the morphology (indicated by arrows) is due to the mechanical or physical action of microorganisms on PVC surface film as reported by Webb and co-workers ${ }^{[12]}$.

The untreated PCL film (Figure 5a) had a rough surface while the surface of the PCL in the soil (buried for 30 days) (Figure 5b) had holes (arrow), cracks, and rough structures (arrow) throughout the film. In the PCL film treated in soil for 30 days with leachate are shown craters appeared (Figure 5c). These morphological alterations reflect the microbial action on film: mechanical (adhesion) and enzymatic reactions, which includes ester hydrolysis and chain oxidation as confirmed by the FTIR results.

The untreated PVC/PCL 1:1 blend had a smooth surface, similar to that of untreated film PVC (Figure 6a). After treatment in microbial soil for 120 days, the formation of a variety of structures is seen, suggesting microbial adhesion (red arrow) (Figure 6b). The film treated in soil with leachate (Figure 6c) showed some morphological changes similar to those in the film treated in soil

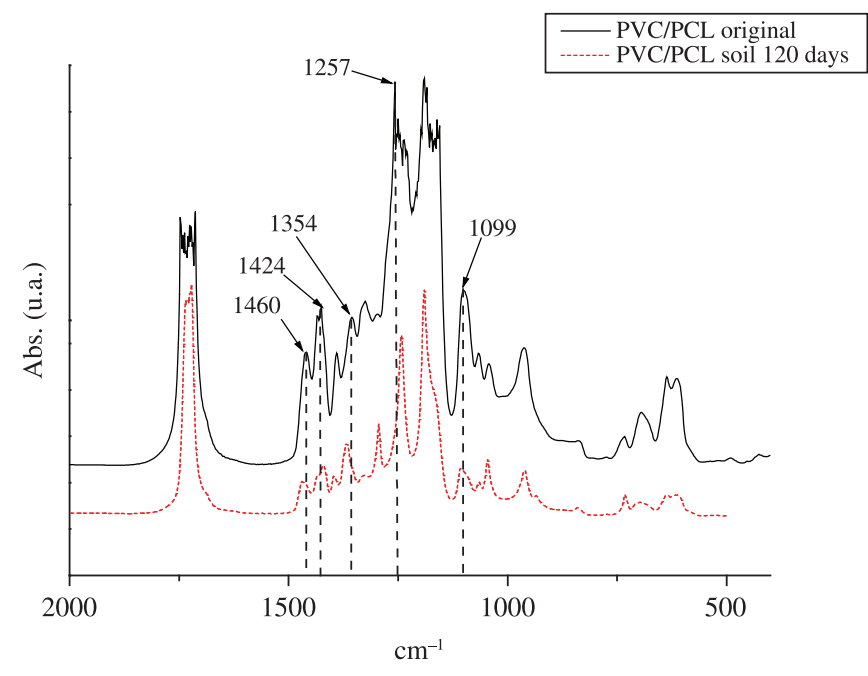

(a)

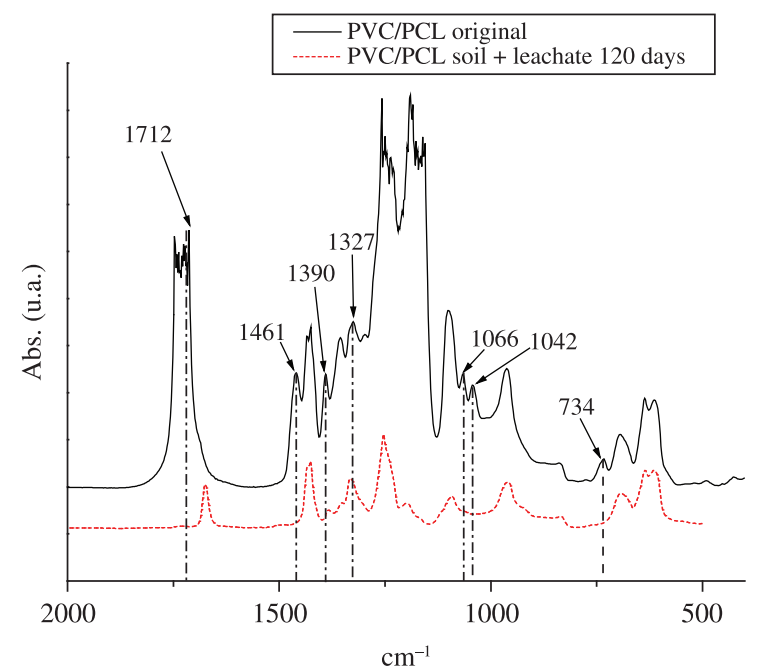

(b)

Figure 3. FTIR absorption spectra of the PVC/PCL films before and after 120 days in treatment: a) soil, b) soil with leachate.

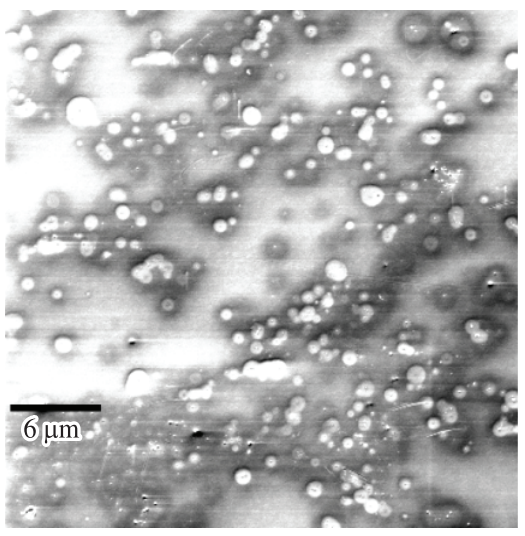

(a)

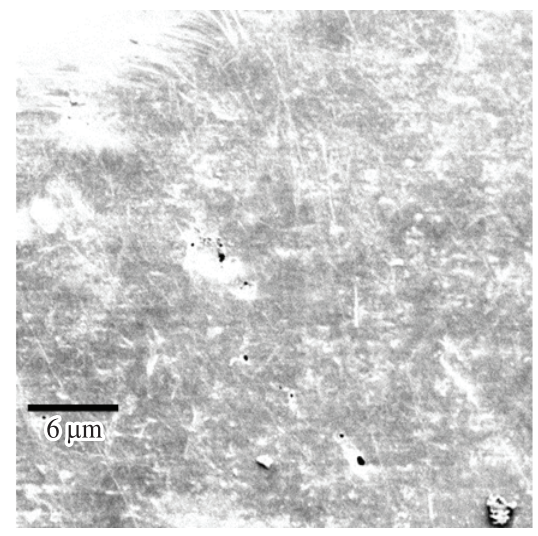

(b)

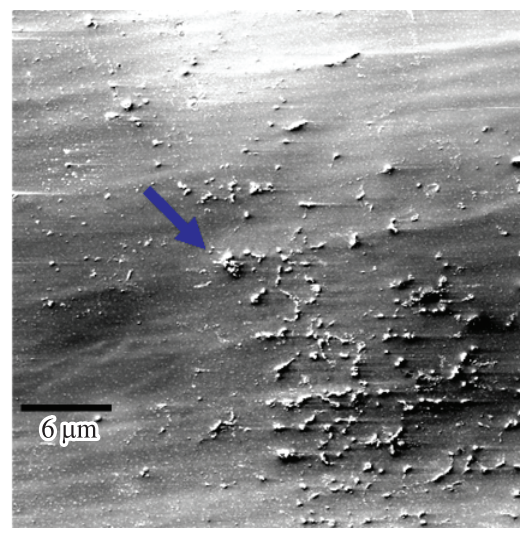

(c)

Figure 4. SEM images of PVC films: a) original, b) after 120 days in soil microbial action, c) after 120 days in soil with leachate microbial action. 
alone. These changes are compatible with the weight loss and structural changes observed by FTIR and DSC.

Morphological changes due to degradation may occur at sites of instability, such as chain ends, chain folds, and the edge of the crystals, where the chain mobility appears to be higher. The degradation of lamellar edges may lead to lamellar thinning and melting at slightly lower temperature than the original crystals ${ }^{[30]}$.

In this case, the biodegradation of PVC/PCL blends, occurs especially in the PCL phase. On the PVC surface microorganism adhesion occurs, changing the morphology. X-ray studies with PVC/PCL blends obtained by dichloroethane evaporation, showed that PVC suffered morphology changes with chemi-chrystallization, analogous to that found when semi-crystalline polymers are photodegraded $^{[31]}$.

\section{Differential scanning calorimetry (DSC)}

PVC, PCL and PVC/PCL 1:1 films were characterized thermally by DSC. The melting points and heat of fusion were obtained from the DSC curves, in order to calculate the degree of crystallinity of the films before and after the microbial treatment, using Equation $1^{[32]}$. (Equation 1)

$$
\% \chi_{c}=\frac{\Delta H_{f}}{\Delta H_{100 \%}} \chi 100
$$

Where $\% \mathrm{Xc}$ is crystallinity index (in percentage), $\Delta \mathrm{H}_{\mathrm{f}}$ is the enthalpy of fusion of the polymer (obtained by DSC) and $\Delta \mathrm{H}_{100 \%}$ is the value for the $100 \%$ crystalline polymer.

The original PVC films (amorphous), prepared with the solvent $\mathrm{DMF}$, had a low glass transition temperature, $\mathrm{Tg}\left(60^{\circ} \mathrm{C}\right)$, suggesting that residual DMF acted as a plasticizer, causing an increase in the free volume of the polymer matrix. In PVC, the chlorine normally tends to anchor the polymer chain in the solid matrix, raising the energy level needed for chain mobility and increasing the $\mathrm{Tg}$ of the polymer in the absence of plasticizer ${ }^{[33]}$.

The Tgs of the PVC films treated with soil and soil with leachate were higher $\left(67-69{ }^{\circ} \mathrm{C}\right)$ than for the original film $\left(60{ }^{\circ} \mathrm{C}\right)$, but lower than that of PVC without plasticizer $\left(80-85^{\circ} \mathrm{C}\right)^{[9]}$. After the treatment, there was a perceptible hardening of the films (Figure 7), as observed when the plasticizer leaves the film.

DSC curve of the PCL (semi-crystalline) in soil (Figure 8a) is similar to that for the original PCL film, with a slight change in shape, suggesting better organization of the crystalline phase, however, the crystalline fraction of original PCL is the same of that treated in soil, because the crystalline regions were degraded at the same rate as the amorphous regions, the ratio of amorphous material to crystalline material remained constant as verified by Luo $\&$ Netravali ${ }^{[34]}$ in studies of PHBV degradation in composting.

The DSC curves of the PCL treated in soil and leachate (Figure 8b), showed no significant change in the shape of the melting

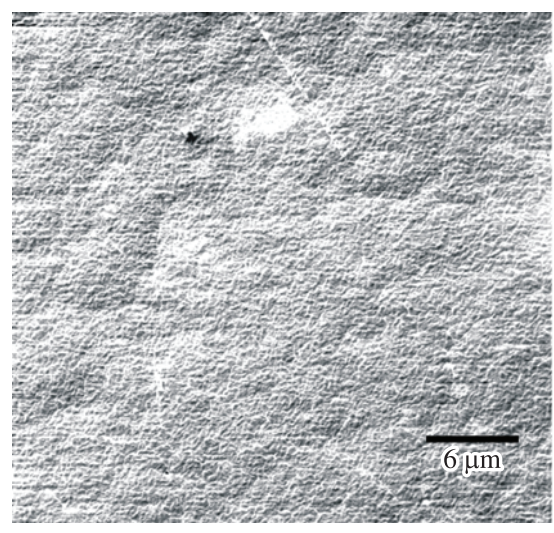

(a)

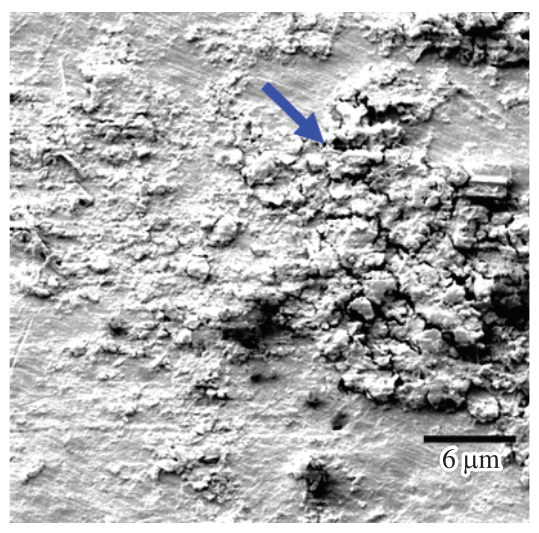

(b)

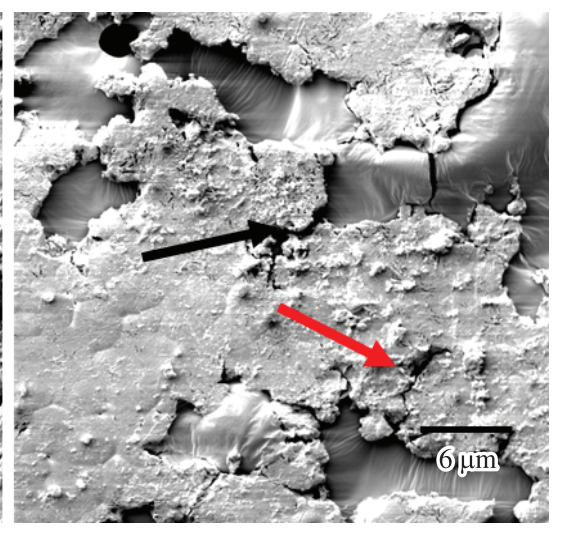

(c)

Figure 5. SEM images of PCL films (200x): a) original, b) after 30 days in soil microbial action, c) 30 days in soil with leachate microbial action.

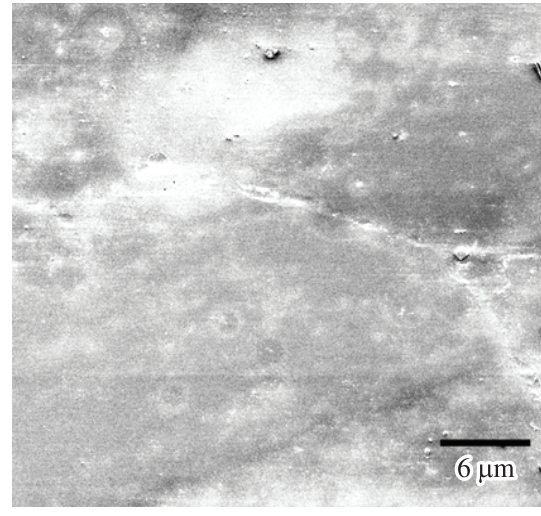

(a)

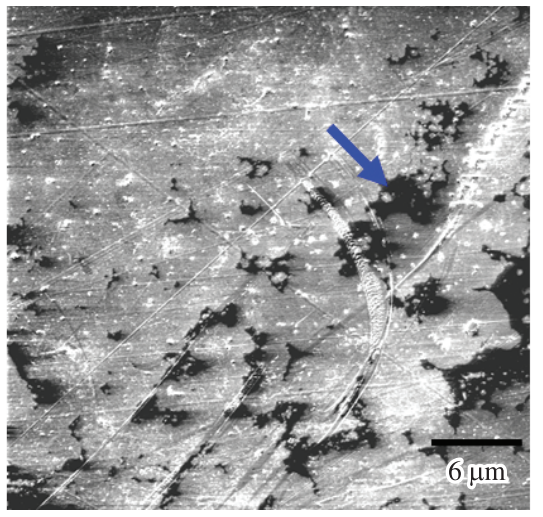

(b)

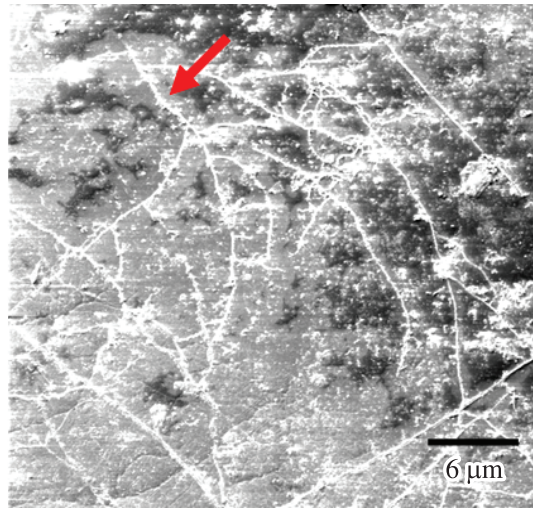

(c)

Figure 6. SEM of PVC/PCL films (200x): a) original, b) after 120 days in soil microbial action and c) after 120 days in soil with leachate microbial action. 
peak, but the temperature of melting increased slightly, suggesting better organization of the chains. This agrees with the results of respirometry, in which the evolution of $\mathrm{CO}_{2}$ was slower in the case of films treated with soil and leachate (Figure 1b), indicating a lower biodegradability. The films in soil treated with leachate showed surface degradation, observed in measurements of the contact angle and SEM images, or surface erosion, but with no significant changes in the polymer chains, observed by FTIR.

The DSC curves for PVC/PCL films (Figure 9) exhibit one melting peak, attributed to the PCL melting in the blend. When the blend was treated with soil microorganisms (Figure 9a), there was an increase in the value $\Delta \mathrm{H}_{\mathrm{f}}$, corresponding to a rise in the crystalline fraction of PCL in the blend, due to reorganization of the chains after the microbial action, as observed by Contat-Rodrigo and coworkers ${ }^{[35]}$. The blend in soil treated with leachate showed similar results to the blend in soil without leachate.
Figure 9 shows that the presence of PVC in the blend reduces the original crystalline fraction in the PCL. According to Chiu \& $\mathrm{Min}^{[36]}$ the size of the PCL spherulites is almost independent of the composition of the PVC/PCL blend, but smaller spherulites can occur on the addition of PVC to PCL. There is also a fall in the melting temperature of the PCL, indicating greater disorder, a larger amorphous phase in the PCL and greater interaction with the PVC, as discussed by Calil and coworkers ${ }^{[2]}$ and Karal and coworkers ${ }^{[6]}$. The second (crystallization) peak is insignificant and will not be taken into account in the analysis. This is also visible in Figure $9 \mathrm{~b}$.

The following DSC parameters are shown in Table 2: Melting and glass transition temperatures, crystallinity and heat of fusion of the PVC, PCL and PVC/PCL films.

The $\mathrm{Tg}$ of PVC increased after treatment in soil and soil with leachate, owing to the hardening of the film and possible loss of solvent, which was acting as a plasticizer.

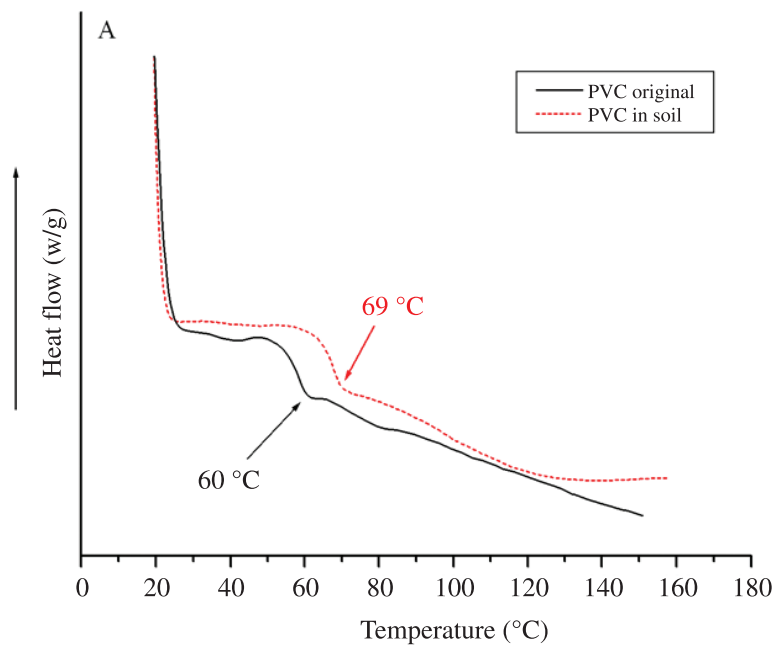

(a)

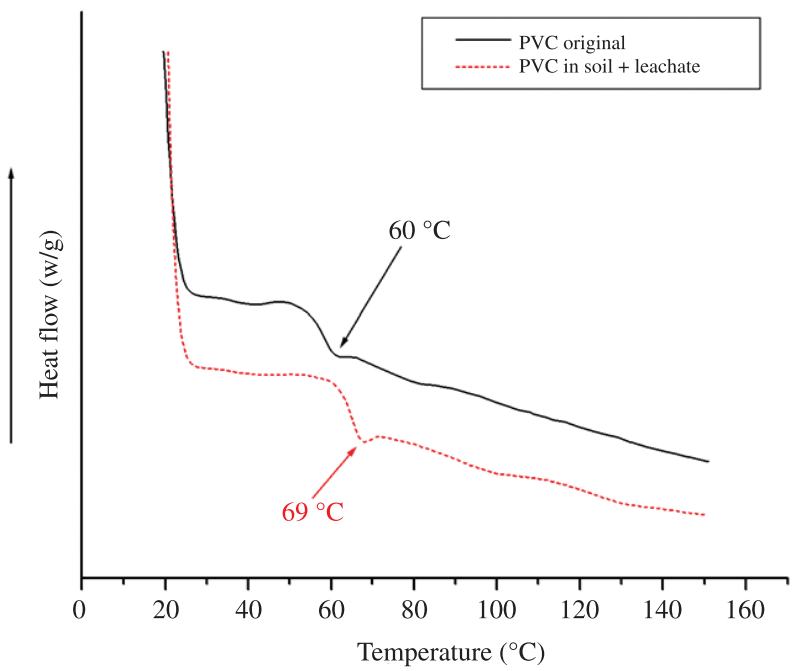

(b)

Figure 7. DSC curve of original PVC films and films treated in: a) soil, b) soil with leachate

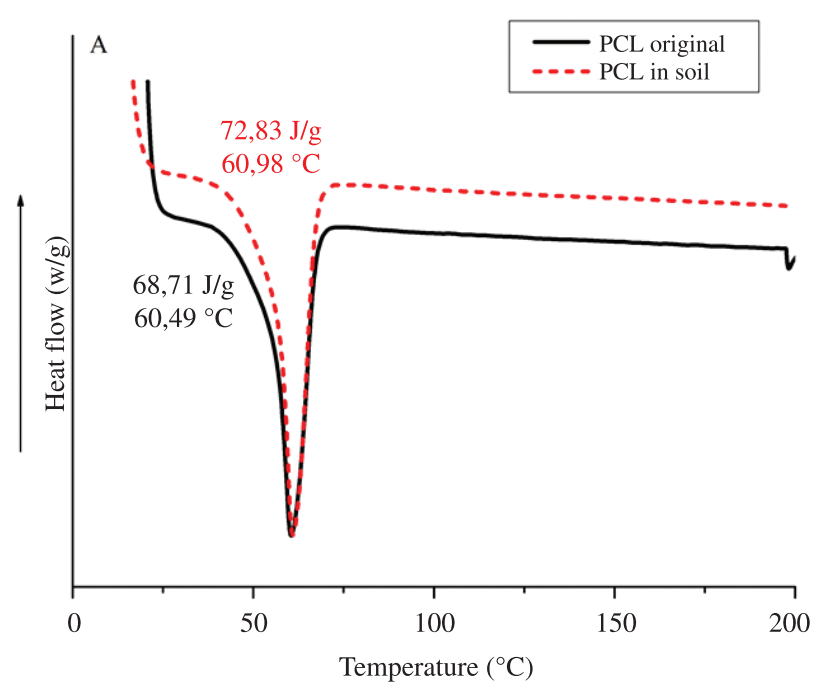

(a)

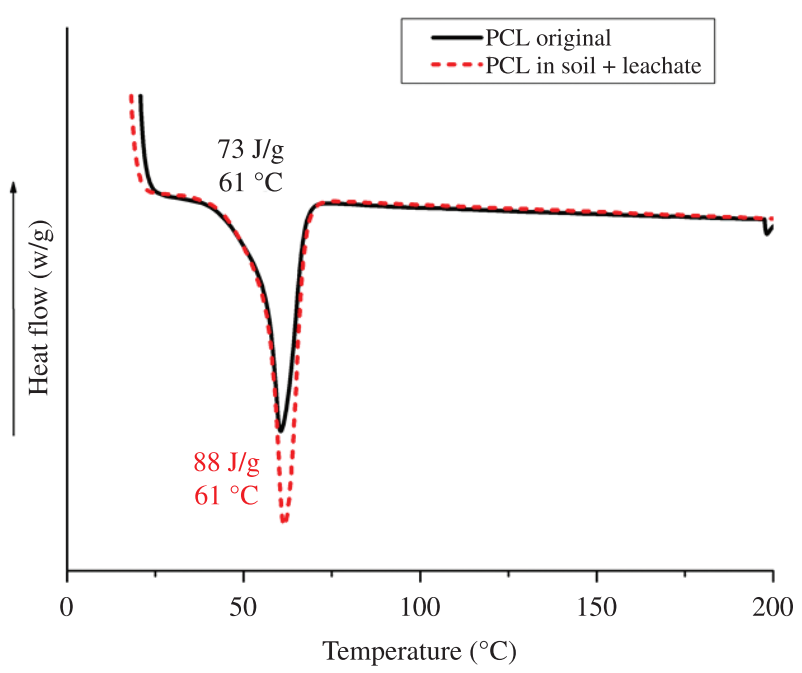

(b)

Figure 8. DSC curve of original PCL films and films treated in: a) soil, b) soil with leachate. 


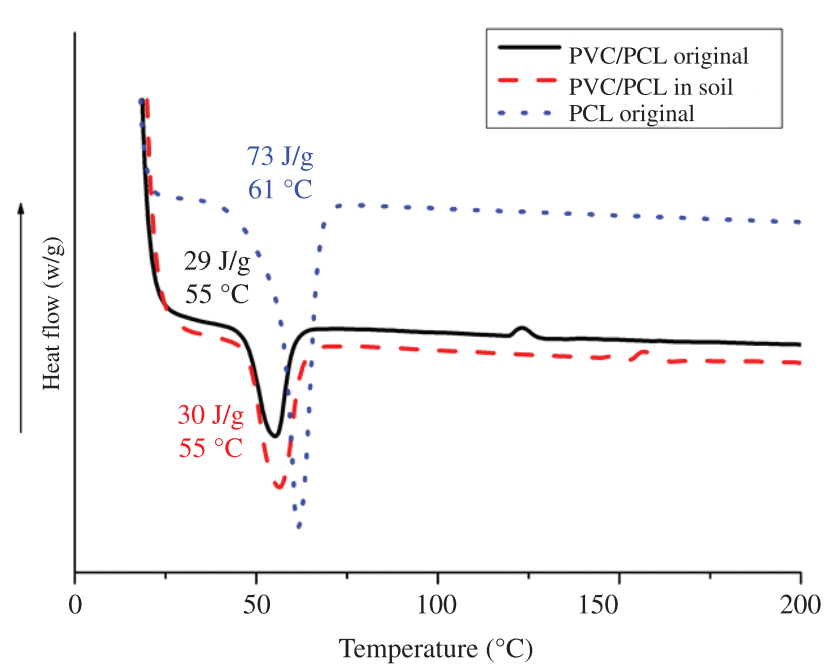

(a)

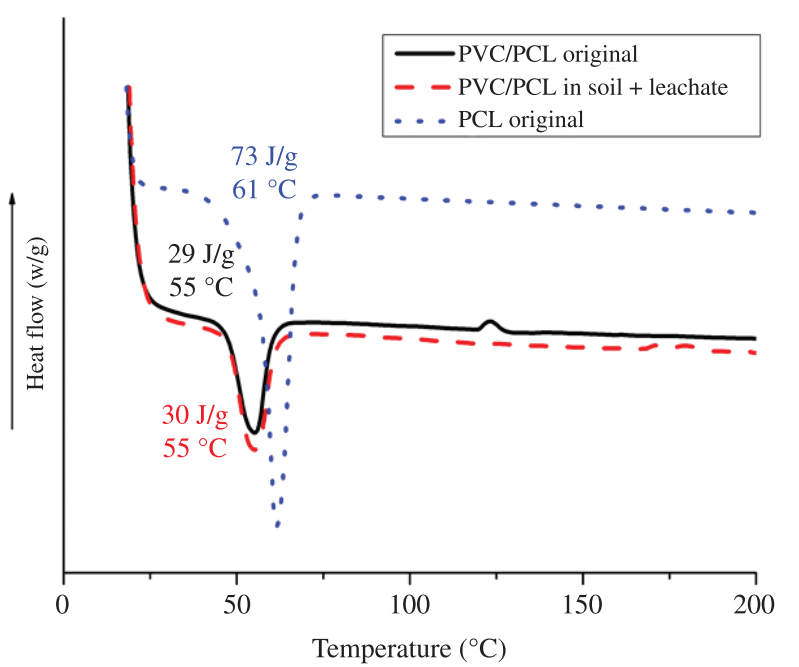

(b)

Figure 9. DSC curve of original PVC/PCL films and films treated: a) soil, b) soil with leachate.

Table 2. Parameters obtained from the thermograms of PVC, PCL and PVC/PCL 1:1 samples. $\mathrm{T}_{\mathrm{f}}\left({ }^{\circ} \mathrm{C}\right)=$ melting temperature, $\mathrm{X}_{\mathrm{DSC}}=$ crystallinity index (\%) from $\Delta \mathrm{H}_{\mathrm{f}}$ obtained by DSC. Reference: $100 \%$ crystalline PCL, $\Delta \mathrm{H}_{\mathrm{f}}=136 \mathrm{~J}^{\mathrm{g}} \mathrm{g}^{-1[21]}$.

\begin{tabular}{|c|c|c|c|c|}
\hline Samples & $\operatorname{Tg}^{\circ} \mathrm{C}$ & $\mathbf{T}_{\mathrm{f}}{ }^{\circ} \mathbf{C}$ & $\Delta \mathbf{H}_{\mathrm{f}}\left(\mathrm{J} \cdot \mathrm{g}^{-1}\right)$ & $\mathrm{X}_{\mathrm{DSC}}(\%)$ \\
\hline PVC original (o) & 60 & ------ & ------------- & \\
\hline PVC in soil (s) & 69 & & & \\
\hline $\begin{array}{l}\mathrm{PVC} \text { in } \\
\text { soil+leachate }(\mathrm{s}+1)\end{array}$ & 67 & ------ & -- & \\
\hline PCL (o) & & 61 & 73 & 54 \\
\hline PCL (s) & & 61 & 73 & 54 \\
\hline PCL (s+1) & & 61 & 88 & 64 \\
\hline PVC/PCL (o) & & 55 & 29 & 43 \\
\hline PVC/PCL (s) & & 56 & 41 & 60 \\
\hline PVC/PCL (s+l) & & 55 & 30 & 45 \\
\hline
\end{tabular}

Table 3. Weight loss of the polymer films after the microbial treatment.

\begin{tabular}{lcc}
\hline \multicolumn{1}{c}{ Films } & $\begin{array}{c}\text { \% weight loss } \\
\text { (soil) }\end{array}$ & $\begin{array}{c}\text { \% weight loss } \\
\text { (soil+leachate) }\end{array}$ \\
\hline PVC 120 days & $1.0 \pm 0.7$ & $1.3 \pm 0.7$ \\
PCL 30 days & $12.4 \pm 0.7$ & $19.8 \pm 0.7$ \\
PCL 45 days & $34.2 \pm 0.7$ & $20 \pm 0.8$ \\
PCL 60 days & $89.7 \pm 0.7$ & $22 \pm 0.7$ \\
PVC/PCL 120 days & $1.9 \pm 0.5$ & $1.6 \pm 0.5$ \\
\hline
\end{tabular}

The crystallinity of the PCL increased after the microbial action of the soil, suggesting increased degradation of the PCL amorphous phase and a reorganization of the polymer chains ${ }^{[33]}$. The presence of the PVC in the blends of PVC/PCL lowered the $T_{f}$ of the PCL, indicating that the carbonyl group of the PCL interacted with the $\mathrm{HC}-\mathrm{Cl}$ group of PVC, according to Calil and coworkers ${ }^{[2]}$ and Karal and coworkers ${ }^{[6]}$. The microbial treatment of the blend in soil provoked an increase in the PCL crystallinity in the blend. It is generally assumed that the various PCL depolymerases preferentially attack the amorphous regions of the semi-crystalline PCL, in view of the well-known inverse dependence of degradation rate on PCL crystallinity ${ }^{[3]}$.

\section{Weight loss}

The percentage of weight loss of the films, measured by weighting them before and after being exposed to the leachate, are shown in Table 3.

The weight losses of the PCL and PVC/PCL films was higher when treated in the soil without leachate. This result shows that the original soil microbial community was more active than when various other microorganisms present in leachate were added, reducing the total microbial activity. One should also take into account that the microbial population of the leachate was pre-selected by the storage temperature $\left(8^{\circ} \mathrm{C}\right)$ before the biodegradation treatment.

The weight loss of PVC film was negligible after 120 days, while the PCL films were completely biodegraded by 90 days in the soil, when it was no longer possible to find the film in the soil. In the PVC/PCL blend, there was no improvement in the biodegradation of the PVC, but the PCL lost much less weight in relation to the homopolymer PCL. This result, taken with the respirometric tests (Figure 1), indicates an intermolecular interaction between the two polymers, i.e., between the groups $\mathrm{HC}-\mathrm{Cl}$ of the $\mathrm{PVC}$ and $\mathrm{C}=\mathrm{O}$ of the PCL, which made the PCL much less susceptible to biodegradation $^{[6,22]}$.

\section{Conclusions}

The PCL was highly degraded after 60 days in soil, and completely decomposed after 90 days. However, when present in blends of PVC/PCL, its degradation was delayed. This was due to the interaction between the polymers making the PCL much less susceptible to microbial attack. PCL is protected by PVC, which controls the biodegradation process. PVC is deteriorated by fungal adhesion and its morphology influences the PCL degradation in the blend.

The addition of leachate to the soil reduced the degradation rate of both the PCL and the blend, thus demonstrating that the soil microorganisms in their usual habitat are more able to attack the film than in the soil contaminated with leachate.

\section{Acknowledgements}

The authors acknowledge FAPESP (Brazil) for a doctoral grant (Process no 04/14381-7). 


\section{References}

1. Singh, R. P.; Pandey, J. K.; Rutot, D.; Degée, P. H. \& Dubois, P. H. - Carbohyd. Res., 338, p.1759 (2003). http://dx.doi.org/10.1016/ S0008-6215(03)00236-2

2. Calil, M. R.; Gaboardi, C. G. F. \& Rosa, D. S. - Polym. Test, 25, p.597 (2006). http://dx.doi.org/10.1016/j.polymertesting.2006.01.019

3. Khatiwala, V. K.; Shekhar, N.; Aggarwal, S. \& Mandal, U. K. J. - Polym. Environ., 16, p.61 (2008). http://dx.doi.org/10.1007/ s10924-008-0104-9

4. Zhao, Q.; Tao, J.; Yam, R. C. M.; Mok, A. C. K.; Li, R. K. Y. \& Song, C. - Polym. Degrad. Stabil., 93, p.1571 (2008). http://dx.doi. org/10.1016/j.polymdegradstab.2008.05.002

5. Darwis, D.; Mitomo, H.; Enjoj, T.; Yoshii, F. \& Makuuchi, K. - Polym. Degrad. Stabil., 62, p.259 (1998). http://dx.doi.org/10.1016/ S0141-3910(98)00005-6

6. Karal, O.; Hamurcu, E. \& Baysal, B. M. - Polym. Degrad. Stabil., 38, p.6071 (1997)

7. Ma, D.; Zhang, J.; Wang, M.; Ma, J. \& Luo, X. - Macromol. Chem. Physic., 202, p.961 (2001). http://dx.doi.org/10.1002/1521-3935(2001 0401)202:7\%3C961::AID-MACP961\%3E3.0.CO;2-Q

8. Kamo, T.; Kondo, T.; Kodera, Y.; Sato, Y. \& Kushiyama, S. - Polym. Degrad. Stabil., 81, p.187 (2003). http://dx.doi.org/10.1016/ S0141-3910(03)00088-0

9. Nunes, L. R. - “Tecnologia do PVC”, ProEditores, Braskem, São Paulo (2006).

10. Pospisil, J.; Horak, Z.; Krulis, Z.; Nespurek, S. \& Kuroda, S. - Polym. Degrad. Stabil., 65, p.405 (1999). http://dx.doi.org/10.1016/ S0141-3910(99)00029-4

11. Veronelli, M.; Mauro, M. \& Bresadola, S. - Polym. Degrad. Stabil., 66, p.349 (1999). http://dx.doi.org/10.1016/S0141-3910(99)00086-5

12. Webb, J. S.; Van Der Mei, H. C.; Nixon, M.; Eastwood, I. M.; Greenhalgh, M. \& Read, S. - Appl. Environ. Microbiol., 65, p.3575 (1999).

13. Braun, E. J. \& Howard, R. J. - Exp. Mycol., 18, p.211 (1994). http:// dx.doi.org/10.1006/emyc.1994.1021

14. Owen, E. D. \& Read, R. L. - Eur. Polym. J., 15 p.41 (1979). http:// dx.doi.org/10.1016/0014-3057(79)90246-5

15. Matsuaka, K.; Tanaka, A. \& Murakami, I. - Polymer, 25, p.1337 (1984). http://dx.doi.org/10.1016/0032-3861(84)90387-2

16. Kirbas, Z.; Keskin, N. \& Güner, A. B. - Environ. Contam. Tox., 63, p.335 (1999). http://dx.doi.org/10.1007/s001289900985

17. Associação Brasileira de Normas Técnicas - ABNT. - "NBR 14283: Resíduos em solo - Determinação da biodegradação pelo método respirométrico", ABNT, São Paulo (1999).
18. Campos, A.; Martins-Franchetti, S. M.; Marconato, J. C.; Agnelli, J. A. M. \& Monteiro, M. R. - Res. J. Biotech., 2, p.20 (2007). http://dx.doi. org/10.1002/biot.200790008

19. Raij, B.; Andrade, J. C.; Cantarella, H. \& Quaggio, J. A., editors. - "Análise química para avaliação da fertilidade de solos", Instituto Agronômico, São Paulo (2001).

20. Campos, A. \& Martins-Franchetti, S. M. - Braz. Arch. Biol. Technol., 48, p.235 (2005). http://dx.doi.org/10.1590/S1516-89132005000200010

21. Kesel, C.; Vander Wauven, C.; David, C. - Polym. Degrad. Stabil., 55, p.107 (1999). http://dx.doi.org/10.1016/0141-3910(95)00138-7

22. Martins-Franchetti, S. M.; Campos, A.; Egerton, T. A. \& White, J. R. - J. Mater. Sci., 43, p.1063 (2008). http://dx.doi.org/10.1007/ s10853-007-2210-9

23. Christensen, P. A.; Egerton, T. A.; Martins-Franchetti, S. M.; Jin, C. \& White, J. R. - Polym. Degrad. Stabil., 93, p.305 (2008). http://dx.doi. org/10.1016/j.polymdegradstab.2007.08.008

24. Guerzoni, M. E.; Sinigaglia, M. \& Gardini, I. - Microbiol. Res., 149, p.115 (1994). http://dx.doi.org/10.1016/S0944-5013(11)80105-9

25. Lucas, N.; Bienaime, C.; Belloy, C.; Queneudec, M.; Silvestre, F. \& Nava-Saucedo, J.E. - Chemosphere, 73, p.429 (2008). PMid: 18723204. http://dx.doi.org/10.1016/j.chemosphere.2008.06.064

26. Luo, H.; Meng, X.; Cheng, C.; Dong, Z.; Zhang, S. \& Li, B. - J. Phys. Chem., 114, p.4739 (2010).

27. Keroack, D.; Zhao, Y. \& Prud'homme, R. E. - Polymer, 40, p.243 (1998). http://dx.doi.org/10.1016/S0032-3861(98)00187-6

28. Wang, Y. \& Yang, J. F. - J. Polym. Res., 17, p.221 (2010). http://dx.doi. org/10.1007/s10965-009-9308-5

29. Martins-Franchetti, S. M. \& Muniz, D. K. - Arq. Inst. Biol., 69, p.103 (2002).

30. Sekosan, G. \& Vasathan, N. J. - Polym. Sci.: Part B: Polym. Physics, 48, p.202 (2009). http://dx.doi.org/10.1002/polb.21889

31. Martins-Franchetti, S. M.; Egerton, T. A. \& White, J. R. - J. Polym. Environ., 18, p.79 (2010). http://dx.doi.org/10.1007/s10924009-0158-3

32. Quental, A. C.; Hanamoto, L. S. \& Felisberti, M. I. - Polímeros, 15, p.281 (2005). http://dx.doi.org/10.1590/S0104-14282005000400013

33. Canevarolo, S. V. J. - "Técnicas de Caracterização de Polímeros", Ed. Artliber, São Paulo (2004).

34. Luo, S. \& Netravali, A. N. - Polym. Degrad. Stabil., 80, p.59 (2003). http://dx.doi.org/10.1016/S0141-3910(02)00383-X

35. Contat-Rodrigo, L.; Ribes-Greus, A. \& Diaz-Calleja, R. - J. Appl. Polym. Sci., 82, p.2174 (2001). http://dx.doi.org/10.1002/app.2065

36. Chiu, F. C. \& Min, K. - Polym. Intern., 49, p.223 (2000). http://dx.doi. org/10.1002/(SICI)1097-0126(200002)49:2\%3C223::AID-PI345\%3E 3.0.CO;2-U

Enviado: 03/01/11

Reenviado: $24 / 07 / 11$

Aceito: $10 / 08 / 11$ 